\title{
Peningkatan Hasil Belajar Siswa Kelas IX-A Pada Pelajaran Bahasa Indonesia Materi Melaporkan Peristiwa Dengan Menggunakan Metode Think Pair Share
}

\author{
Kartini \\ kartiniarpega@gmail.com \\ SMP Negeri 3 Kota Kediri
}

\begin{abstract}
Indonesian Language learning in SMP Negeri 3 Kediri, especially in class IX-A SMP Negeri 3 Kediri in the academic year 2016/2017 has several obstacles in the learning process. In the first semester the results of student learning were still low so that they did not reach the value of the KKM Indonesian language lesson which was 78. One way that can be done by the teacher is to use a new learning method. The learning method is Think Pair Share. Think Pair Share is a method that emphasizes students to discuss with pairs (pairs) to solve the problems given by the teacher, students share (share) with their classmates by presenting their opinions with their partners. The application of this method starts from the teacher giving the task to the students to prepare a report of events, then students in small groups of 2 students. Students compile reports of events and then read them in front of the class. This method can train student cooperation because students share with their friends in compiling reports and also practice courage, especially in reading reports of events in front of their friends. This classroom action research aims to improve student learning outcomes. The indicator of the success of this study is that $75 \%$ of students pass KKM. Based on research data, it can be seen that there are $45 \%$ (15) students completing KKM. Then, in the first cycle there are 70\% (23) students complete KKM. Then, in the second cycle there were $79 \%$ (26) students completed KKM. The data showed an increase from pre-cycle to cycle II. And the success of the study is in accordance with the indicators of success obtained during cycle II, which is $79 \%$ of students complete KKM or more than $75 \%$ of students complete KKM
\end{abstract}

Keywords: Indonesian Language Learning, Learning Outcomes, Think Pair Share.

\begin{abstract}
Abstrak
Pelajaran Bahasa Indonesia di SMP Negeri 3 Kediri, khususnya di kelas IX-A SMP Negeri 3 Kediri tahun pelajaran 2016/2017 memilki beberapa kendala dalam proses pembelajaran. Pada semester I hasil belajar siswa masih rendah sehingga tidak mencapai nilai KKM pelajaran Bahasa Indonesia yaitu 78. Salah satu cara yang dapat dilakukan oleh guru adalah menggunakan sebuah metode pembelajaran baru. Metode pembelajaran tersebut adalah Think Pair Share. Think Pair Share adalah metode yang menitikberatkan siswa untuk berdiskusi dengan pasanganya(pairs) untuk memecahkan masalah yang diberikan oleh guru, siswa berbagi(share) kepada teman-teman sekelasnya dengan mempresentasikan hasildiskusinya dengan pasangannya. Penerapan metode ini dimulai dari guru memberikan ugas kepada siswa untuk menysusun laporan peristiwa, selanjutnya siswa berkelompok kecil beranggotakan 2 siswa. Siswa menyusun laporan peristiwa dan kemudian membacakan di depan kelas. Metode ini dapat melatih kerjasama siswa karena siswa saling berbagi (share) kepada temannya dalam menyusun laporan dan juga melatih keberanian terutama dalam membacakan laporan peristiwa di hadapan
\end{abstract}




\title{
Efektor, Volume 6 Issue 1, 2019, Pages 19 - 25
}

Kartini

\begin{abstract}
teman-temannya. Penelitian tindakan kelas ini bertujuan untuk meningkatkan hasil belajar siswa.Indikator keberhasilan dari penelitian ini adalah terdapat $75 \%$ siswa yang lolos KKM .Berdasarkan data penelitian terlihat bahwa pada prasiklus terdapat 45\% (15) siswa tuntas KKM. Lalu, pada siklus I terdapat 70\% (23) siswa tuntas KKM.Kemudian, pada siklus II terdapat 79\% (26) siswa tuntas KKM.Data tersebut memperlihatkan terjadi peningkatan dari prasiklus sampai siklus II. Dan keberhasilan penelitian sesuai dengan indikator keberhasilan didapat saat siklus II, yaitu $79 \%$ siswa tuntas KKM atau lebih dari $75 \%$ siswa tuntas KKM.
\end{abstract}

Kata Kunci: Pelajaran Bahasa Indonesia, Hasil belajar, Think Pair Share.

\section{PENDAHULUAN}

Bahasa memiliki peran sentral dalam perkembangan intelektual, sosial, dan emosional peserta didik dan merupakan penunjang keberhasilan dalam mempelajari semua bidang studi.Pembelajaran bahasa Indonesia diarahkan untuk meningkatkan kemampuan peserta didik untuk berkomunikasi dalam bahasa Indonesia dengan baik dan benar, baik secara lisan maupun tulis, serta menumbuhkan apresiasi terhadap hasil karya kesastraan manusia Indonesia (Depdiknas, 2008). Bahasa diperlukan individu untuk mengelola pikiran mereka. Menurutnya kita melambangkan dan menggambarkan dunia kita melalui bahasa, sehingga bahasa adalah sistem simbolik dengan apa kita berkomunikasi, atau dengan kata lain bahasa adalah alat budaya (Permana, 2015).

Proses pembelajaran Bahasa Indonesia di SMPN 3 Kediri mengalami beberapa kendala. Siswa kelas IX sudah dipersiapkan untuk menghadapi UN (Ujian Nasional). Tetapi setelah dilakukan tes, hasil belajar siswa masih rendah. Hal ini diketahui setelah siswa mengerjakan tes ulangan yang diberikan oleh guru. Hasil tes yang didapat rata-rata hanya 45\% siswa yang tuntas KKM. Salah satu cara untuk menyelesaikan permasalahan ini adalah dengan sebuah metode pembelajaran. Diperlukan sebuah metode pembelajaran yang tepat untuk menciptakan susana belajar yang menyenangkan, sehingga nantinya akan membuat siswa dapat menerima pelajaran dengan baik. Metode pembelajaran tersebut adalah Think Pair Share (Wahyuni, 2012).

Think Pair Share (TPS) dikembangkan oleh Frank Lyman dan Spencer Kagan sebagai struktur kegiatan pembelajaran kooperatif. Teknik ini memberi siswa kesempatan untuk bekerja sendiri serta bekerja sama dengan orang lain. Keunggulan lain dari teknik ini adalah optimalisasi partisipasi siswa. Dengan metode klasikal yang memungkinkan hanya satu siswa maju dan membagikan hasilnya untuk seluruh kelas.Teknik Think Pair Share ini memberi kesempatan sedikitnya delapan kali lebih banyak kepada setiap siswa untuk dikenali dan menunjukan partisipasi mereka kepada orang lain. Teknik ini bisa digunakan dalam semua mata pelajaran dan untuk semua tingkatan usia anak didik.

Berdasarkan uraian masalah di atas, maka tujuan dari penelitian ini adalah Meningkatkan hasil belajar siswa kelas IX A SMPN 3 Kediri pada pelajaran Bahasa Indonesia materi melaporkan peristiwa melalui metode pembelajaran Think Pair Share di semester I tahun pelajaran 2016/2017. Proses pembelajaran Bahasa Indonesia di kelas IX-A SMPN 3 Kediri mengalami beberapa kendala. Kendalanya adalah rendahnya hasil belajar siswa yang belum mencapai nilai KKM, yaitu 78. Oleh sebab itu, diperlukan metode pembelajaran yang mampu meningkatkan hasil belajar siswa. Metode pembelajaran yang dapat membuat siswa bersemangat dalam mengikuti proses pembelajaran.

\section{METODE PENELITIAN}

Penelitian tentang pembelajaran melaporkan peristiwa menggunakan metode Think Pair Share ini dilaksanakan di SMP Negeri 3 Kota Kediri.Secara khusus penelitian dilakukan di kelas IX-A, karena permasalahan muncul di kelas tersebut. Penelitian ini merupakan penelitian tindakan kelas atau Classroom Action Research (Arikunto, 2006). Penelitian Tindakan Kelas merupakan suatu bentuk penelitian yang berbentuk reflektif dengan melakukan tindakan tertentu untuk memperbaiki dan 
meningkatkan praktik pembelajaran di kelas secara lebih berkualitas sehingga siswa dapat memperoleh hasil belajar yang lebih baik (Permana \& Imron, 2016).

Pada penelitian tindakan kelas ini, bahan penilaian difokuskan pada ranah afektif dan kognitif siswa. Ranah kognitif akan diuji melalui tes ulangan harian. Salah satu solusi yang memungkinkan digunakan oleh guru adalah penggunaan metode pembelajaran Think Pair Share (TPS). Think Pair Share dapat meningkatkan motivasi belajar siswa. Karena siswa akan berdiskusi dengan pasanganya (pairs) untuk memecahkan masalah yang diberikan oleh guru, siswa berbagi (share) kepada temanteman sekelasnya dengan mempresentasikan hasil diskusinya dengan pasangannya. Selain itu dengan penerapan metode ini siswa akan lebih menguasai materi, karena siswa harus berpikir (think) untuk menyelesaikan masalah yang ditugaskan kepadanya.

Tempat dan waktu penelitian ini dilaksanakan di SMPN 3 Kediri. Penelitian ini dilakukan pada bulan Agustus hingga September semester ganjil tahun pelajaran 2016/2017. Subjek dalam penelitian ini adalah siswa kelas IX-A SMPN 3 Kediri yang berjumlah 33 siswa, terdiri dari 14 siswa laki-laki dan 19 siswa perempuan. Objek dalam penelitian ini adalah mata pelajaran Bahasa Indonesia yang khususnya materi melaporkan peristiwa. Materi tersebut terdapat dalam SK (Standar Kompetensi), "Mengungkapkan pikiran, perasaan, dan informasi dalam bentuk komentar dan laporan" dan KD (Kompetensi Dasar) "Melaporkan secara lisan berbagai peristiwa dengan menggunakan kalimat yang jelas"(Depdiknas, 2008).

Data yang telah terkumpul dianalisis secara kritis dengan membandingkan hasil tindakan dalam tiap siklus, kemudian dibandingkan dengan indikator keberhasilan tindakan yang telah ditetapkan. Hasil analisis berupa kelebihan dan kekurangan proses pembelajaran tiap siklus, diarahkan baik pada kinerja guru maupun siswa. Analisis dilakukan secara kolaboratif dengan kolaborator.

\section{HASIL DAN PEMBAHASAN}

Siklus I

Peserta didik berdoa sebelum memulai pelajaran, dan merespon salam motivasi guru untuk menumbuhkan rasa ingin tahu peserta didik. Peserta didik mengamati contoh laporan yang baik, bagaimana membacakan laporan peristiwa dengan benar, dan hal-hal yang harus diperhatikan dalam membacakan laporan. Guru meminta siswa berkelompok dua orang, siswa berkelompok dengan teman satu bangku. Setiap kelompok diminta membuat laporan peristiwa dengan tema bebas. Saat proses diskusi ada beberapa siswa yang kebingungan menyusun laporan, guru menjelaskan kembali laporan yang baik. Setelah selesai, satu siswa dalam setiap kelompok membacakan hasil laporan peristiwa. Sementara kelompok lain menilai hasil pembacaan laporan peristiwa dengan mempertimbangkan teknik-teknik membaca laporan peristiwa yang benar. Begitu seterusnya hingga semua perwakilan kelompok maju membacakan hasil diskusi. Hasil penilaian kelompok dievaluasi oleh guru. Hasil observasi terhadap guru yang dilakukan oleh observer dapat dilihat pada tabel 1.

Secara umum, hasil observasi terhadap guru cukup baik mulai dari penguasaan kelas, penggunaan pendekatan, membimbing siswa, kejelasan penugasan dan sebagainya. Sementara hasil observasi terhadap siswa yang dilakukan oleh observer secara umum observasi baik itu keaktifan siswa dalam bertanya, menjawab pertanyaan guru, antusias siswa dalam belajar, sikap percaya diri, siswa bercanda, siswa malu dan sebagainya menunjukkan jumlah siswa $50 \%$ saja yang aktif. Sementara yang lain belum. Hasil refleksi yang dilakukan oleh observer di siklus I adalah: 1) Berikan tema dalam menyusun laporan observer beranggapan, dengan diberikan tema kreativitas dalam menyusun laporan peristiwa akan lebih terarah, dan setiap kelompok diberikan tema yang berbeda. 2) Setiap pasangan kelompok maju sekaligus untuk membacakan laporan peristiwa,agar siswa berlatih membaca dengan baik.

Siklus II 
Pelaksanaan dalam siklus II mempertimbangkan solusi dan saran yang telah diberikan observer pada siklus I. Guru mempersiapkan RPP dengan metode yang sama dengan sebelumnya, yaitu menggunakan metode Think Pair Share. Namun, terdapat perubahan dalam proses pembelajaran, yaitu memberikan tema untuk laporan peristiwa, dan teama berbeda dari setiap kelompok. Selain itu setiap kelompk maju sekaligus untuk membacakan contoh laporan yang telah dibuat. Hal ini sesuai saran observer untuk melatih keberanian siswa. Menyusun dan mempersiapkan lembar observasi untuk siswa dan guru. Lembar observasi terdiri dari tiga bagian, yaitu lembar refleksi, lembar refleksi untuk guru, dan terakhir lembar observasi untuk siswa. Membuat soal model pilihan ganda sejumlah sepuluh soal untuk siswa yang akan diberikan setiap akhir pelajaran. Soal ini digunakan untuk mengukur seberapa besar kemampuan siswa dalam ranah kognitif menyerap ilmu pengetahuan yang telah diajarkan. Pada siklus ini siswa berkelompok dua orang, guru membentuk kelompok berdasarkan nomor absen dan membedakan kelompok dari siklus I agar melatih siswa untuk bekerja sama dengan temannya. Setiap kelompok diminta membuat laporan peristiwa, setiap kelompok diberikan tema yang berbeda. Siswa diminta menyusun laporan peristiwa. Guru menentukan tema dari peristiwa yang akan disusun. Hal ini sesuai saran observer, agar kreativitas siswa dalam menyusun laporan lebih terarah. Tema tersebut diantaranya: politik, sosial, budaya, pendidikan, bencana alam, dan kecelakaan lau lintas.

Guru menjelaskan dalam proses ini semua siswa harus aktif dalam diskusi menyusun contoh laporan. Setelah selesai, setiap pasangan kelompok membacakan laporan peristiwa yang telah dibuat. Hal ini sesuai saran observer agar semua siswa dapat bagian untuk membacakan laporan peristiwa, dan juga untuk melatih keberanian siswa. Sebelum mulai membaca guru memberikan waktu 5 menit untuk siswa berlatih teknik membaca laporan dengan benar. Kelompok lain diperbolehkan menanggapi hasil unjuk kerja temannya sekaligus memberi penilaian. Guru mengevaluasi hasil pembacaan laporan peristiwa, guru menyarankan kepada siswa untuk sering menonton berita dan memperhatikan reporter yang membacakan laporan perisitiwa, agar siswa lebih memahami teknik membacakan laporan peristiwa yang benar.

Di setiap siklus tindakan, observer selalu mengisi lembar observasi untuk menilai kinerja guru di kelas. Pada beberapa tabel di atas telah dipaparkan data hasil observasi yang dilakukan observer. Pada tabel di bawah terlihat data keseluruhan hasil observasi terhadap guru.

Tabel 1. Data observasi terhadap guru pada Siklus I dan Siklus II

\begin{tabular}{|c|c|c|c|c|c|c|c|c|c|c|c|}
\hline \multirow{3}{*}{ No } & \multirow{3}{*}{ Aspek Pengamatan } & \multicolumn{10}{|c|}{ Hasil Pengamatan } \\
\hline & & \multicolumn{5}{|c|}{ Siklus I } & \multicolumn{5}{|c|}{ Siklus II } \\
\hline & & $\begin{array}{l}\text { SB } \\
(5)\end{array}$ & $\begin{array}{l}B \\
(4)\end{array}$ & $\begin{array}{l}C \\
(3)\end{array}$ & $\begin{array}{l}K \\
(2)\end{array}$ & $\begin{array}{l}\text { KS } \\
\text { (1) }\end{array}$ & $\begin{array}{l}\text { SB } \\
\text { (5) }\end{array}$ & $\begin{array}{l}B \\
(4)\end{array}$ & $\begin{array}{l}C \\
(3)\end{array}$ & $\begin{array}{l}K \\
(2)\end{array}$ & $\begin{array}{l}K S \\
(1)\end{array}$ \\
\hline 1 & Penguasaan kelas & & $x$ & & & & & $x$ & & & \\
\hline 2 & Penggunaan pendekatan & & & $X$ & & & & $X$ & & & \\
\hline 3 & Alokasi waktu & & & $X$ & & & $x$ & & & & \\
\hline 4 & Membimbing siswa & & & $X$ & & & & $X$ & & & \\
\hline 5 & Meragamkan aktivitas siswa & & & & $x$ & & & $X$ & & & \\
\hline 6 & Kejelasan penugasan & & & $X$ & & & & $x$ & & & \\
\hline 7 & $\begin{array}{l}\text { Mengevaluasi hasil kegiatan } \\
\text { siswa }\end{array}$ & & & $X$ & & & $x$ & & & & \\
\hline 8 & $\begin{array}{l}\text { Mendorong siswa mencari } \\
\text { data informasi untuk } \\
\text { menjawab pertanyaan }\end{array}$ & & & $X$ & & & & $X$ & & & \\
\hline 9 & $\begin{array}{l}\text { Mendorong siswa berpikir } \\
\text { kreatif dan aktif }\end{array}$ & & & & $X$ & & & $X$ & & & \\
\hline 10 & Mendorong rasa ingin tahu & & $X$ & & & & $X$ & & & & \\
\hline
\end{tabular}




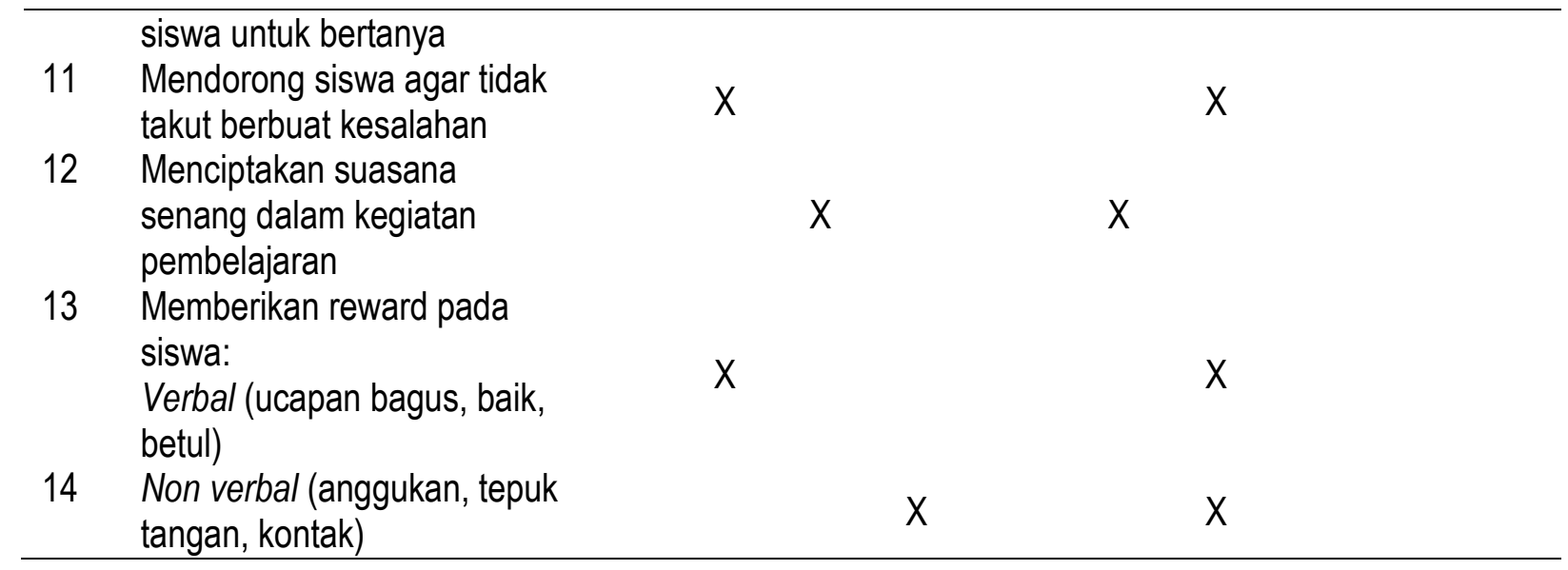

Berdasarkan tabel di atas dapat terlihat dari ke-14 aspek yang diamati oleh observer terhadap guru maka persentase nilai yang didapat guru pada siklus I adalah $\frac{4+3+3+3+2+3+3+3+2+4+4+3+4+2}{70} \times$ $100 \%=61,4 \%$. Dengan demikian, sesuai tabel 2 tentang klasifikasi data nilai kuantitatif, maka pada siklus I penilaian kinerja guru termasuk ke dalam klasifikasi C (Cukup). Pada siklus II persentase nilai yang didapat guru adalah $\frac{4+4+5+4+4+4+5+4+4+5+4+5+4+4}{70} \times 100 \%=85,7 \%$. Dengan demikian, sesuai tabel 1, maka pada siklus II penilaian kinerja guru termasuk ke dalam klasifikasi B (Baik). Data ini memperlihatkan bahwa kinerja guru semakin meningkat dalam proses kegiatan belajar mengajar di siklus PTK. Perilaku siswa dalam setiap siklus terus diamati oleh observer untuk melihat secara fisik tentang perkembangan yang terjadi. Hasil keseluruhan observasi terhadap siswa dapat dilihat pada tabel di bawah ini.

Tabel 2. Data observasi terhadap siswa di Siklus I dan Siklus II

\begin{tabular}{clcc}
\hline $\begin{array}{c}\text { Aspek } \\
\text { Pengamatan }\end{array}$ & \multicolumn{1}{c}{ Uraian Aspek Pengamatan } & \multicolumn{2}{c}{ Jumlah Siswa } \\
Verbal & Siswa bertanya & Siklus II \\
& Siswa mengobrol sendiri di luar materi & $6-10$ & $11-15$ \\
& Siswa dapat menjawab pertanyaan guru & $6-10$ & $<6$ \\
& Siswa bercanda & $11-15$ & $>15$ \\
& Siswa menyahut asal-asalan & $6-10$ & $<6$ \\
Non-verbal & $6-10$ & $<6$ \\
& Siswa antusias belajar & $11-15$ & $>15$ \\
& Siswa percaya diri & $6-10$ & $11-15$ \\
& Siswa malu & $6-10$ & $<6$ \\
& Siswa bermain-main sendiri & $<6$ & 0 \\
& Siswa tidur-tiduran & 0 & 0 \\
& Siswa menyimak guru & $11-15$ & $>15$ \\
& Siswa terlibat aktif & $11-15$ & $>15$ \\
& Siswa menghargai hasil kerja teman & $6-10$ & $11-15$ \\
& Siswa terlambat masuk kelas & $<6$ & 0 \\
\hline
\end{tabular}

Data pada tabel di atas memperlihatkan hasil observasi yang dilakukan observer terhadap perilaku siswa di kelas saat PTK dilaksanakan. Pada tabel 12 terdapat beberapa aspek penilaian yang terbagi dalam aspek negatif dan positif. Pada aspek positif seperti siswa bertanya, menjawab pertanyaan guru, antusias belajar, percaya diri, menyimak guru, terlibat aktif, dan menghargai hasil kerja teman terlihat jumlah siswa yang melakukannya meningkat. Hal ini memperlihatkan bahwa pada siklus penelitian yang dilakukan terjadi perubahan positif pada aspek-aspek yang positif.Aspek negatif 
seperti Siswa mengobrol sendiri di luar materi, bercanda, malu, bermain-main sendiri, dan terlambat masuk kelas terjadi penurunan di siklus kedua. Bahkan aspek-aspek negatif tersebut tidak terlihat lagi di siklus kedua.

Sedangkan pada aspek negatif siswa menyahut asal-asalan dan tidur-tiduran tidak ditemukan pada semua siklus penelitian. Oleh sebab itu, data pada tabel 16 memperlihatkan bahwa observer menilai hasil penelitian tindakan yang dilakukan oleh peneliti (guru) adalah mampu meningkatkan aspek positif pada siswa, dan mampu mengurangi aspek negatif pada siswa.

Analisis postest ini dilakukan untuk menjawab tujuan penelitian, yaitu meningkatkan hasil belajar siswa kelas IX-A SMPN 3 Kediri semester I tahun pelajaran 2016/2017 pada mata pelajaran Bahasa Indonesia materi melaporkan peristiwa dengan menggunakan metode pembelajaran Think Pair Share. Dengan analisis ini akan diketahui apakah terjadi peningkatan prestasi belajar siswa dalam setiap siklus PTK atau tidak, dengan cara melihat ketercapaian siswa dalam KKM yaitu minimal 78.

Untuk mengetahui persentase ketercapaian KKM siswa di setiap siklus, rumus yang digunakan adalah:

$$
\frac{\text { jumlchsiswalolosKKM }}{\text { jumlchsiswakeselurihan }} \times 100 \%
$$

Telah diketahui bahwa jumlah siswa kelas IX-A SMPN 3 Kediri adalah 33 orang.

Tabel 3. KKM siswa setiap siklus dan persentasenya

\begin{tabular}{lccc}
\hline & Prasiklus & Siklus I & Siklus II \\
\hline Jumlah siswa tuntas KKM & 15 & 23 & 26 \\
\% siswa lolos KKM & $45 \%$ & $70 \%$ & $79 \%$ \\
Rata-rata nilai siswa & 69,1 & 78,2 & 82,4 \\
\hline
\end{tabular}

Tabel di atas memperlihatkan kenaikan jumlah siswa yang mencapai ketuntasan minimal di setiap siklus. Indikator keberhasilan dari penelitian ini adalah terdapat $75 \%$ siswa yang lolos KKM. Berdasarkan data pada tabel 3 dapat dilihat bahwa pada prasiklus terdapat 45\% (15) siswa tuntas KKM.Lalu, pada siklus I terdapat $70 \%$ (23) siswa tuntas KKM. Kemudian, pada siklus II terdapat $79 \%$ (26) siswa tuntas KKM. Data tersebut memperlihatkan terjadi peningkatan dari prasiklus sampai siklus II. Dan keberhasilan penelitian sesuai dengan indikator keberhasilan didapat saat siklus II, yaitu $79 \%$ siswa tuntas KKM atau lebih dari $75 \%$ siswa tuntas KKM.

Nilai rata-rata unjuk kerja siswa di setiap siklus mengalami kenaikan. Pada prasiklus nilai ratarata siswa hanya 69,1 atau masih di bawah KKM. Pada siklus I nilai rata-rata siswa adalah 78,2. Pada siklus II nilai rata-rata siswa meningkat menjadi 82,4 atau telah berada di atas KKM. Berdasarkan data pada tabel 3, dapat disimpulkan bahwa penggunaan metode pembelajaran Think Pair Share mampu meningkatkan hasil belajar siswa pada pelajaran Bahasa Indonesia dalam materi melaporkan peristiwa siswa kelas IX-A SMPN 3 Kediri semester I tahun pelajaran 2016/2017.

\section{SIMPULAN}

Hasil penelitian dengan menerapkan metode pembelajaran Think Pair Share pada pelajaran Bahasa Indonesia kelas IX-A SMPN 3 Kediri tahun pelajaran 2016/2017 berjalan dalam dua siklus penelitian. Setiap siklus penelitian terdiri atas dua kali pertemuan. Setiap pertemuan terdiri atas 2 jam pelajaran (4 x 40 menit). Telah berhasil meningkatkan hasil belajar siswa. Penerapan metode ini dimulai dari guru memberikan tugas kepada siswa untuk menyususun laporan peristiwa, selanjutnya siswa berkelompok kecil beranggotakan 2 siswa. Siswa menyusun laporan peristiwa dan kemudian membacakan di depan kelas. Metode ini dapat melatih kerjasama siswa karena siswa saling berbagi (share) kepada temannya dalam menyusun laporan dan juga melatih keberanian terutama dalam membacakan laporan peristiwa di hadapan teman-temannya.

Indikator keberhasilan dari penelitian ini adalah terdapat $75 \%$ siswa yang lolos KKM. Berdasarkan data penelitian terlihat bahwa pada prasiklus terdapat $45 \%$ (15) siswa tuntas KKM.Lalu, 
pada siklus I terdapat 70\% (23) siswa tuntas KKM. Kemudian, pada siklus II terdapat 79\% (26) siswa tuntas KKM. Data tersebut memperlihatkan terjadi peningkatan dari prasiklus sampai siklus II. Keberhasilan penelitian sesuai dengan indikator keberhasilan didapat saat siklus II, yaitu 79\% siswa tuntas KKM atau lebih dari 75\% siswa tuntas KKM. Dapat disimpulkan bahwa metode pembelajaran Think Pair Share mampu meningkatkan hasil belajar siswa kelas IX-A SMPN 3 Kediri pada pelajaran Bahasa Indonesia materi melaporkan peristiwa.

\section{DAFTAR PUSTAKA}

Arikunto, S. (2006). PROSEDUR PENELITIAN TINDAKAN KELAS. Bumi Aksara, 136(2), 2-3.

Depdiknas. (2008). Permendiknas No 22 tahun 2006. Tentang Standar Isi Pendidikan Dasar dan Menengah. Jakarta.

Permana, E. P. (2015). PENGEMBANGAN MEDIA PEMBEJARAN BONEKA KAUS KAKI UNTUK MENINGKATKAN KETERAMPILAN BERBICARA SISWA KELAS II SEKOLAH DASAR. Profesi Pendidikan Dasar, 2(2), 133-140.

Permana, E. P., \& Imron, I. F. (2016). Penerapan Pembelajaran IPS Dengan Media Ular Tangga Untuk Meningkatkan Minat Belajar Siswa Kelas IV SDN Kecamatan Prambon Nganjuk. EFEKTOR, 3(2), 58. Retrieved from http://ojs.unpkediri.ac.id/index.php/efektor-e/article/view/493

Wahyuni, T. (2012). Implementasi Cooperative Learning Tipe Think-Pair-Share pada Pembelajaran IPS. Journal of Educational Social Studies, 1(2), 119-124. 